\title{
Analysis of knowledge assessment results of civil servants regarding anti-corruption issues
}

\author{
Olga Astafurova ${ }^{1 *}$, Ada Golomanchuk $^{2}$, Tatyana Omelchenko ${ }^{3}$, Anna Borisova ${ }^{4}$, and Julia Kayushnikova ${ }^{5}$ \\ ${ }^{1}$ Volgograd Institute of Management - Branch of the Russian Academy of National Economy and Public Administration under the \\ President of the Russian Federation, 8 Gagarina str., Volgograd, 400066; Volgograd, Russian Federation. astoa@vlgr.ranepa.ru \\ 2 Volgograd Institute of Management - Branch of the Russian Academy of National Economy and Public Administration under the \\ President of the Russian Federation, 8 Gagarina str., Volgograd, 400066; Volgograd, Russian Federation. golomanchukav@mail.ru \\ ${ }^{3}$ Volgograd State University, 100 Prospect Universitetsky, Volgograd; Volgograd, Russian Federation \\ ${ }^{4}$ Volgograd Institute of Management - Branch of the Russian Academy of National Economy and Public Administration under the \\ President of the Russian Federation, 8 Gagarina str., Volgograd, 400066; Volgograd, Russian Federation. borisova-as@mail.ru \\ ${ }^{5}$ Volgograd Institute of Management - Branch of the Russian Academy of National Economy and Public Administration under the \\ President of the Russian Federation, 8 Gagarina str., Volgograd, 400066; Volgograd, Russian Federation. kayshnikova@yandex.ru.
}

\begin{abstract}
The article presents the program shell developed by the authors to estimate the knowledge of civil servants regarding anti-corruption issues. This development is a part of an information and analysis system, which is aimed not only at automating the analysis of data on knowledge control but it also includes both educational functions and possibilities for automation of the activity of the personnel divisions on the prevention of corruption offenses, formation of maps of corruption risks, observation, study and forecast of deviant corruption-related changes in the conduct of civil servants, assignment of testing, organization of training, etc. Due to the introduction of this program, the personnel divisions will obtain both systemic organization of awareness-raising measures (lectures, seminars) involving servants and the possibility to estimate their psychological condition and the general base of knowledge regarding prohibitions and restrictions in the civil service, practical and theoretical nuances of providing data about income, expenses, assets, liabilities, etc. The authors consider the issues of the introduction of the programs in the state authorities of both federal and regional levels. They point out the need to take into account the peculiarities of the targeted information system of the organization : the compatibility of the development being introduced with the current version of the operating system, as well as the security policy of the targeted system. The study presents the first results of the testing of the software product and includes an assessment of their main factors.
\end{abstract}

\section{Introduction}

Corruption processes taking place in society are one of the urgent challenges to social well-being and national security as a whole [1], [2], [3]. Manifestations of corruption at the level of state authorities are the most dangerous as they interrupt the normal functioning of both these structures and the entire state system [4]. There are thematic seminars, lectures, testing organized to raise the legal awareness and the level of legal literacy of civil servants regarding anti-corruption issues and to prevent corruption offenses in the civil service [5], [6], [7].

Modern information technology can considerably facilitate the development of this area of activities. For example, the information and analysis system aimed at informational support of the process of gaining anticorruption knowledge and skills on the basis of modern information technology [8], [9], [10], [11], [12], [13], [14].
This information and analysis system is developed within the framework of the grant of the Russian Foundation for Basic Research "Formation of an AntiCorruption Environment in State and Municipal Authorities through Introducing the Information and Analysis System 'Anti-Corruption Methods and Tactics for Civil and Municipal Servants"”. Any information system implies the automation of particular functions. The system under consideration ensures an integrated approach to solving the problems of anti-corruption education, stage-by-stage control of the implementation of measures, objective assessment of their results, analysis of the anti-corruption environment and forecasting of its development. The use of the software product will make it possible to cease to process information manually and reduce the possibility of errors during data processing and compilation of analytical reports [15].

\section{Problem Statement}

\footnotetext{
* Corresponding author: astoa@vlgr.ranepa.ru
} 
The organization of using any software is associated with certain difficulties of introducing new technologies. It requires all kinds of settings and often enhancement of specific functions and integration with other systems in compliance with the reality of the organizational structure and management procedures.

It is necessary to take into account the peculiarities of the targeted information system of the organization during the deployment of software products. In particular, not only the compatibility between the versions of operating systems of one family but also the compatibility of the development being introduced with the current update version of each given operating system can turn out critical.

In addition, certain difficulties and restrictions can follow from the security policy of a particular targeted system. In this regard, the deployment of the software product in each given information system gives rise to problems which are impossible to consider at the stage of testing of the software. As a result, the settlement of such problems falls on engineers and administrators. Consequently, development and adjustment of the software product do not provide any guarantee that it will be applied effectively.

The user's qualification is a significant aspect of this problem. Programs with considerable functional possibilities, as a rule, have a complex interface capable of providing users with a huge number of tools. They are intended for professional users, i.e. experts whose main activity is the operation of a particular program. Software with a simpler set of tasks can be managed by ordinary users that refer to it only from time to time, if needed, for example, to take tests. In this case the efficiency of the software operation depends on the availability of the interface ensuring an intuitive understanding of the principles of interaction with the program and the promptness of obtaining the result.

\section{Research Questions}

The main objective of software developers is to bring their development as close as possible to the needs of the customer. Even at the design stage it is important to involve potential users in the development process, to form their requirements.

In general, the introduction of the information system turns out more difficult than the use of small program packages. This is due to particular organizational difficulties and the complexity of adjustment of the software product. Moreover, large software products do not always ensure fast information processing. As a rule, this is caused by an incomplete understanding of how to use the possibilities of the new system.

Another argument in favor of the development of a separate program shell for testing is the request of users to have the possibility to take tests (to watch video lectures and other materials) using mobile devices.

Based on the above, it was decided to develop a simple program shell that includes a testing subsystem of the information and analysis system being developed with its further transfer to the mobile version.
The testing system is a program module performing the functions of user authorization, selection of a test from the list of available tests, the examination of users in terms of the selected test with the results saved in the database for further analysis, as well as functions related to the analyst account, which are limited in this version of the program.

This software product was designed for Windows 7 and Windows 10 operating systems by means of MS Visual Studio 2019 in the C\# programming language. The list of system requirements has two main components: NetFramework - ensures the functioning of the developed software product, and MSSQLlocalDB - ensures interaction with databases. These components are included in the installation package, which checks their availability and compliance of their versions at the beginning of the installation. As a result of the check, in case the mentioned components are not available or the versions are not adequate, they are downloaded and installed. A computer restart may be required to complete the installation of some components.

The stage of identification and deployment of the components is followed by the installation of the software product itself. During the installation, it is necessary to select the folder for the program files. It is strongly recommended not to install the software product into system folders, such as Program Files or Windows, to avoid problems during work with the software database. After the installation is complete, a shortcut to run the Tests of Corruption program appears on the desktop.

Every launch of the software product opens the login form, in which the user is asked to enter the name or any other sequence of characters (hereinafter "login") that uniquely identify the person taking a test. Every user of the program must use his or her own login to ensure correct processing of the testing results. This requirement is due to the fact that the first time when users enter their logins, they are simultaneously registered in the list of accounts stored in a special database intended for this purpose. Afterward, the use of a formerly registered login causes addition or update of data of the tests taken under the given account. It is necessary to consider the case sensitivity - a difference in one capital letter of the login will result in the registration of a new account. This simplified authorization system is applied to reduce the time for introduction and testing at this stage of studies. The program contains an integrated analyst (personnel officer) account protected by a password. In this version of the software product the analyst account makes it possible to access information about all accounts registered in the course of operation of the program and the testing results. To implement these functions, the login into the analyst account launches the corresponding interface that is different from the interface of interaction with other users.

After the login into a standard account, the software product opens a window that provides the possibility to select any test from the suggested list. The corresponding testing form is created and opens after the test is selected. The following form components can be 
defined as common for all the tests: the output area for the current question, the output area for the answer options for the current question, the timer and the confirm button for the selected answer. As a rule, using the mouse is enough to interact with the test forms, but it is also possible to use hot keys to save time and provide more comfort to the person taking the test. Every test should be completed within a particular time period, after which the test closes automatically and the current test result is saved in the database. During the testing the user can track the elapsed time with the timer located in the form.

The result is saved in the database after each testing. The saved information includes the login of the person taking the test, the date and time of the testing. The number of scored points is recorded as the number of correct answers or according to the scales approved on the basis of the assessment technique, which depends on the type of testing.

\section{Purpose of the Study}

The purpose of this study is not so much to develop a software product and test it on the basis of executive authorities as to analyze the results of knowledge assessment, to enhance the methods and approaches related to the processing of the obtained data.

\section{Research Methods}

Working on the article, we applied various principles of psychology, in particular, the principle of the unity of consciousness and activity by S.L. Rubinstein, the concept of system determination of mental phenomena by B.F. Lomov, the principle of development. The theoretical framework of the study includes the basic provisions of V.N. Myasishchev's psychological concept of relations and V.A. Yadov's dispositional concept with regard to the study of psychological peculiarities of money relations, as well as the theory of personality development by A. Maslow and L.I. Antsyferova.

Research methods. The Questionnaire for Assessment of Money Behavior of Civil Servants was created to achieve the set objectives. It is based on a set of diagnostic techniques, which includes as follows:

1 - Technique by Yu.M. Semenov,

2 - Technique by A. Furnham,

3 - Technique by E.B. Fantalova, Level of Correlation between Value and Availability (the authors' version),

4 - Technique by A.M. Poleev,

5 - Dembo-Rubinstein self-assessment technique (the authors' version),

6 - Authors' scale of monetary satisfaction.

The reliability of the research results is ensured by the methodological substantiation of the applied approaches and research methods, use of complementary techniques, special selection of persons for tests among civil servants and check of correctness of the selection of persons for tests, control of the empirical research procedure, comparative analysis of the results.

\section{Findings}

In the course of testing of the software, the findings were obtained according to four techniques for tests: the program for assessment of the psychological prerequisites for employees' corrupt practices (hereinafter "test 1"), the program for assessment of employees regarding anti-corruption issues (hereinafter "test 2"), the program for assessment of the civil servants' awareness regarding the provision of data about income (hereinafter "test 3"), the program for assessment of employees' deviations (hereinafter "test 4").

The technique of test 1 implies the assessment of the answers according to seven set scales, in a similar way, the technique of test 4 assesses the answers of the persons taking tests according to six set scales. Each scale has a threshold value - the norm the excess of which indicates particular deviations in the behavior. As a result of the conducted tests, the average indices for each of the scales of the tests as well as the indices of maximum deviation from the norm among the persons taking tests were calculated.

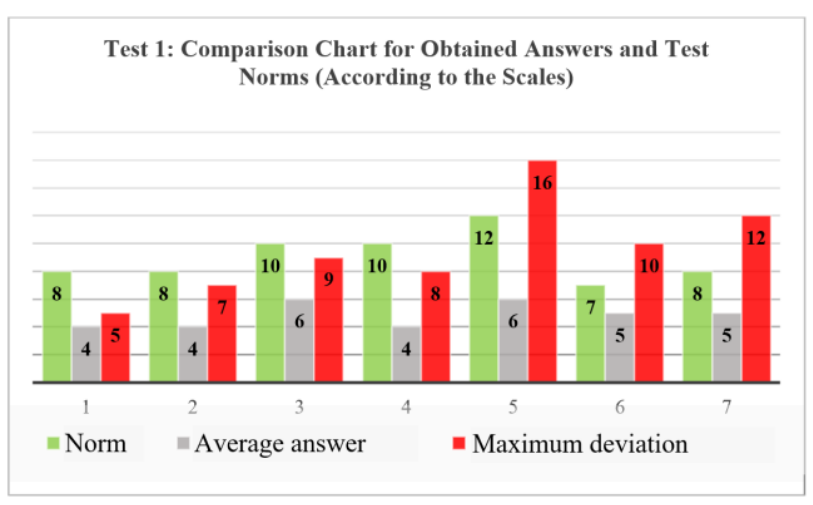

Figure 1. The results of the assessment of the psychological prerequisites for employees' corrupt practices ("test 1")

Table 1. The technique of test 1

\begin{tabular}{|l|l|l|}
\hline $\begin{array}{l}\text { Scale } \\
\text { No. }\end{array}$ & Name of Scale & Description of Deviations \\
\hline 1 & $\begin{array}{l}\text { Social } \\
\text { desirability } \\
\text { attitude }\end{array}$ & $\begin{array}{l}\text { Excess of the norm - } \\
\text { dishonest answers }\end{array}$ \\
\hline 2 & $\begin{array}{l}\text { Tendency to } \\
\text { overcome norms } \\
\text { and rules }\end{array}$ & $\begin{array}{l}\text { Excess of the norm - } \\
\text { unwillingness to obey laws } \\
\text { and norms }\end{array}$ \\
\hline $\begin{array}{l}\text { Tendencies to to } \\
\text { addictive } \\
\text { behavior }\end{array}$ & $\begin{array}{l}\text { Excess of the norm - } \\
\text { incapability of accepting } \\
\text { reality and resisting } \\
\text { obstacles (partially - } \\
\text { tendency to corruption) }\end{array}$ \\
\hline 4 & $\begin{array}{l}\text { Tendency to self- } \\
\text { injurious and } \\
\text { self-destructive } \\
\text { behavior }\end{array}$ & $\begin{array}{l}\text { Excess of the norm - } \\
\text { dissatisfaction with oneself, } \\
\text { tendency to act deliberately } \\
\text { in a "bad", "wrong" way }\end{array}$ \\
\hline 5 & $\begin{array}{l}\text { Tendency to } \\
\text { aggression and } \\
\text { violence }\end{array}$ & $\begin{array}{l}\text { Excess of the norm - } \\
\text { excessive aggression }\end{array}$ \\
\hline
\end{tabular}




\begin{tabular}{|l|l|l|}
\hline 6 & $\begin{array}{l}\text { Volitional } \\
\text { control } \\
\text { emotional } \\
\text { reactions }\end{array}$ & $\begin{array}{l}\text { Excess of the norm - high } \\
\text { degree of self-control }\end{array}$ \\
\hline 7 & $\begin{array}{l}\text { Tendency to } \\
\text { corrupt behavior }\end{array}$ & $\begin{array}{l}\text { Excess of the norm - } \\
\text { tendency to corruption and } \\
\text { other deviations }\end{array}$ \\
\hline
\end{tabular}

According to the results of the first test, it is possible to assume that the average indices of all the scales are within the norm, and even the maximum deviations exceed the threshold value only of three of seven scales (Figure 1, Table 1).

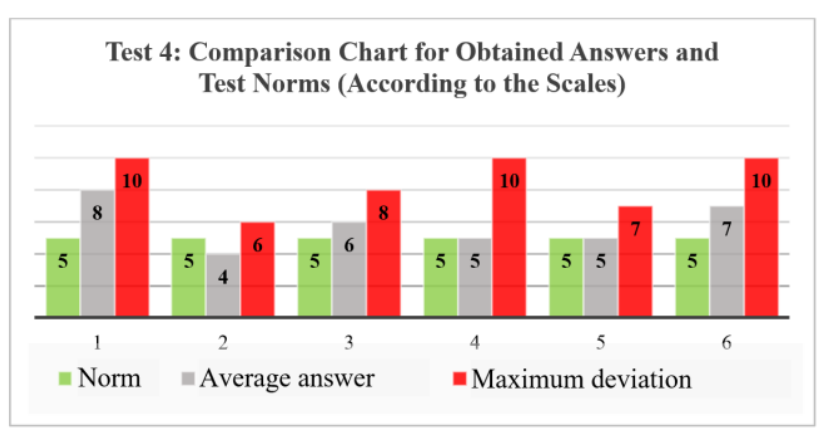

Figure 2. The results of the assessment of the employees' deviations ("test 4")

Table 2. The technique of test 4

\begin{tabular}{|l|l|l|}
\hline $\begin{array}{l}\text { Scale } \\
\text { No. }\end{array}$ & Name of Scale & Description of Deviations \\
\hline 1 & Social desirability & $\begin{array}{l}\text { Excess of the norm - } \\
\text { dishonest answers }\end{array}$ \\
\hline 2 & $\begin{array}{l}\text { Tendency to } \\
\text { violation of } \\
\text { norms and rules }\end{array}$ & $\begin{array}{l}\text { Excess of the norm - } \\
\text { unwillingness to obey } \\
\text { laws and norms }\end{array}$ \\
\hline 3 & $\begin{array}{l}\text { Stress tolerance } \\
\text { Excess of the norm - low } \\
\text { resistance to stress, high } \\
\text { exposure to stress }\end{array}$ \\
\hline 5 & $\begin{array}{l}\text { Control of } \\
\text { emotional } \\
\text { reactions }\end{array}$ & $\begin{array}{l}\text { Excess of the norm - high } \\
\text { degree of self-control }\end{array}$ \\
\hline 6 & $\begin{array}{l}\text { Tendency to risk } \\
\text { aggression } \\
\text { violence }\end{array}$ & $\begin{array}{l}\text { Excess of the norm - high } \\
\text { tendency to risk }\end{array}$ \\
\hline
\end{tabular}

The results of the fourth test demonstrate a greater number of deviations from the norm. The average indices and maximum deviations of most scales border or exceed the norm (Figure 2, Table 2).

The technique of test 2 and test 3 implies calculation of points by the number of correct answers. The maximum number of points for test 2 is 20 (20 questions), and for test $3-45$ (45 questions).

The subject of testing is the knowledge of legal rules in the area of corruption. To analyze the results of tests, the same ranges were selected according to the number of correct answers, and the number of persons taking tests within each range was calculated. The number is expressed as a percentage.

Test 2: Distribution of Persons Taking Test According to the Number of Correct Answers

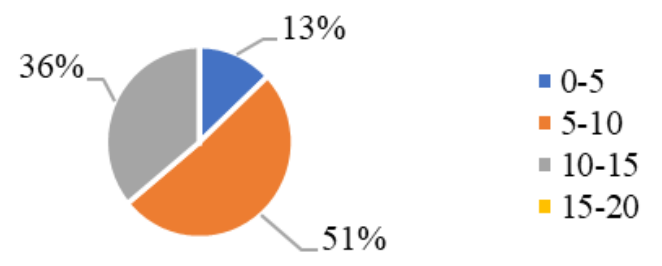

Figure 3. The results of the assessment of the civil servants' awareness regarding provision of data about income ("test 2")

The results of test 2 are indicative of insufficient training of the persons taking tests in respect of anticorruption issues (Figure 3).

Test 3: Distribution of Persons Taking Test According to the Number of Correct Answers

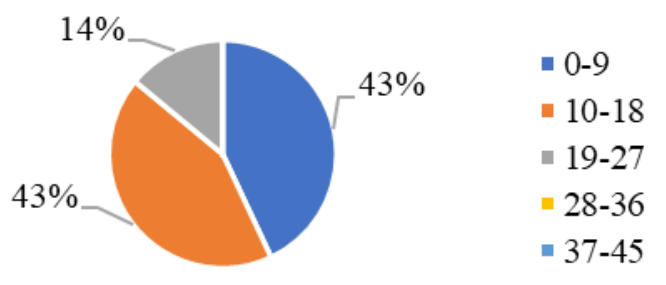

Figure 4. The results of the assessment of the civil servants' awareness regarding the provision of data about income ("test 3")

The results of test 3 are indicative of insufficient training of the persons taking tests in respect of the provision of data about income (Figure 4).

\section{Conclusion}

The introduction of the information and analysis system in the activity of divisions countering corruption and other offenses will make it possible to develop the field of corruption prevention and enhance anti-corruption education. The proposed software product will automate the assessment of the knowledge of civil servants regarding their possession of the fundamentals of the anti-corruption legislation, provision of data about income, analytics of the psychological condition, money behavior and its prerequisites, evaluation of the tendency of officers to corruption. We are sure that the implementation of the program will significantly simplify the work of personnel divisions, help them to effectively exercise their authorities to prevent corruption offenses among civil servants.

\section{Acknowledgment}

The study was carried out with financial support of the Russian Foundation for Basic Research within the 
framework of scientific project No. 18-29-16119 "Formation of an Anti-Corruption Environment in State and Municipal Authorities through Introducing the Information and Analysis System "Anti-Corruption Methods and Tactics for Civil and Municipal Servants".

\section{References}

1. T. Gulchehra, T. Albina, International Journal of Innovative Technology and Exploring Engineering $9 \quad$ (1), $\quad 3219-3221 \quad$ (2019) doi:10.35940/ijitee.A9159.119119

2. H. Li, T. Meng, Journal of Chinese Political Science $25 \quad$ (3), $431-456 \quad$ (2020) doi:10.1007/s11366-020-09672-w

3. H. Zhang, Y. Song, S. Tan, S. Xia, H. Zhang, C. Jiang, ... Y. Lv, Cities 90, 64-73 (2019) doi:10.1016/j.cities.2019.01.042

4. S.V. Kuznetsov, R.R. Magizov, Y.V. Radzevanovskaya, V.K. Alexey, I.G. Mukhametgaliev, M. Andino, International Journal of Recent Technology and Engineering 7 (6), 99102 (2019)

5. C. Hauser, Journal of Business Ethics 159 (1), 281299 (2019) doi:10.1007/s10551-018-3808-3

6. O.F. Lobazova, International Journal of Innovative Technology and Exploring Engineering 8 (12), 4667-4672 doi:10.35940/ijitee.L3867.1081219

7. J.-H. Meyer-Sahling, K.S. Mikkelsen, Review of Public Personnel Administration (2020) doi:10.1177/0734371X20949420

8. O.A. Astafurova, A.S. Borisova, A.V. Golomanchuk, T.Y. Yagotinsteva, International Journal of Information and Education Technology 10 (3), 209-214 (2020) https://doi: 10.18178/ijiet.2020.10.3.1365.

9. R. Baguma, F. Mutungi, T. Janowski, Paper presented at the ACM International Conference Proceeding Series, 484-494 (2019) doi: $10.1145 / 3325112.3325266$

10. E. Denisova-Schmidt, M. Huber, E. Leontyeva, A. Solovyeva, Empirical Economics 60 (8) (2020) doi:10.1007/s00181-020-01827-1

11. T.K. Mackey, R.E. Cuomo, Global Health Action 13 (1) (2020) doi:10.1080/16549716.2019.1695241

12. A. Mouna, B. Nedra, M. Khaireddine, Transforming Government: People, Process and Policy (2020) doi:10.1108/TG-03-2020-0040

13. C. Strand, M. Hatakka, Anti-corruption efforts in national ICT policies: A study of policy environments in sub-saharan Africa (2019) doi:10.1007/978-3-030-18400-1_43

14. C. Strand, M. Hatakka, Existing and promising theoretical approaches to understanding ICTs contribution to anti-corruption efforts: A literature review (2020) doi:10.1007/978-3-030-39296-3_6
15. O.A. Astafurova, A.S. Borisova, A.V. Golomanchuk, T.A. Omelchenko, International Journal of Information and Education Technology 10 (2), 90-94 (2020) https://doi: 10.18178/ijiet.2020.10.2.1345. 